\title{
The Tribes We Lead: Understanding the Antecedents and Consequences of Brand Evangelism Within the Context of Social Communities
}

\author{
Toni Ann Cestare \\ Wagner College \\ Ipshita Ray \\ Pace University
}

Brand evangelism has significant potential to impact loyalty, thereby making the construct an important point of interest for practitioners and researchers alike. This study attempts to augment existing literature by demonstrating how antecedent constructs such as trust and sentiment operate in unique and distinctive ways when mediated by brand evangelism, especially as it relates to two very different outcome variables in attitudinal and behavioral loyalty. While brand evangelism is found to be a mediator for the impact of sentiment on loyalty, it interestingly does not seem to be a mediator for the impact of trust on loyalty.

Keywords: Brand Evangelism, Social Media, Trust, Loyalty

\section{INTRODUCTION}

Social media continues to permeate all walks of life and further establishes a consumer-centric economy in which consumers greatly influence each other's purchasing decisions (Padmanabhan, 2008). Consumers enjoy social networking sites because these platforms provide a place for them to express themselves easily, find social support and gain a sense of identity while connecting with others (Weinberg et al 2013). According to Shadkam and O'Hara (2013), research by the Nielsen Mckinisey Company shows that approximately $80 \%$ of active Internet users visit blogs and social network sites on a regular basis. These social network sites create communities where consumers can share feedback, reviews, and referrals of products, also known as user-generated content (Chen and Huang, 2012). Consumers make informed decisions based on information not only from firms, but also from other consumers (Shadkam and O'Hara, 2013). This study examines the critical concept of consumers influencing others through brand evangelism. Brand evangelism results from consumers feeling so deeply committed to a brand they consistently and repeatedly advocate for that brand with the intention of persuading other consumers. The firm has little control over a brand evangelist since they are acting on their own. The objective of this study is to supplement extant literature by providing a deep understanding of what influences a consumer to become a brand evangelist in terms of trust and sentiment, and the distinct impact these variables have on attitudinal and behavioral loyalty when mediated by brand evangelism.

Consumers share their experiences in-person through face-to-face interactions with friends, or through technology-mediated channels, such as review websites, mobile apps, and social media. Social 
media provides consumers with a sense of empowerment since they are enabled to extend their reach globally like never before (Laughlin and Mac Donald, 2010). Prior to social media a consumer would be required to call customer service or write a letter if they wanted to talk to or about a brand. Now, consumers can freely engage with brands by sending out "Tweets," "likes," "shares," or "comments" in a plethora of social networking sites such as Twitter, Instagram, Snapchat, Facebook and more. Consumers in New York can engage in real time conversations with other consumers in Europe or Asia via social media channels. Social media dramatically changes the way in which consumers and brands interact by enabling conversations between and among firms and consumers (Thomas et al, 2012). Consumer-brand interactions are multidimensional as they represent a multi-party conversation rather than a one-way conversation of the brand talking to the consumer (Rohm, Kaltcheva and Milne, 2013). This new online conversation has opened the gates to a two-way communication channel and has become the new word of mouth (WOM) known as e-word-of-mouth (eWOM). Due to social media's popularity and ease of use, practitioners are enthusiastically taking advantage of social media channels to connect to consumers (Laroche, Habibi and Richard, 2012).

Social media marketing is at the forefront of marketing strategy in the business world. It is redefining how businesses communicate across their channels of distribution (Rapp et al, 2013) and is an integral component to a successful marketing campaign. Traditionally, brands used a "one size fits all" marketing strategy where marketing messages were crafted to reach all members of the target market. In this digital age of always being "connected" consumers look for ways to connect with brands they identify with, and social media networks provide consumers with this opportunity. Consumers are looking for transparency from brands and ways to engage with the brand (Yan, 2011). Consumers have a desire to participate with brands and become involved in their success, provide feedback, promote their ideas, and collaborate with them (Yan, 2011). It is now necessary for brands to change their communication strategies from top-down communication, but rather build a connection with consumers through engagement in social media networks (Yan, 2011).

Prior to social media and consumers playing such an active role in the brand's marketing strategy, brands were the author of their brand stories (Gensler et al, 2013). With the advent of social media consumers can now share their own brand related stories, which can potentially interrupt and change the brand's intended story. The brand can lose complete control of their message if not carefully managed. As a result, marketing managers increasingly seek out individuals who actively engage in positive word-ofmouth about the brand so that they may be used as brand ambassadors and even advocates. e-WOM facilitates the development of long-term brand advocates and promotes valuable consumer-brand relationships across segments (Cole et al, 2011), thereby reducing customer acquisition costs and positively impacting the brand's bottom line.

Brand evangelism is an extension of positive word-of-mouth communication and goes beyond simple user engagement. Brand evangelism has been defined as the active behavioral and vocal support of a brand, including actions such as purchasing the brand and disseminating positive brand referrals (Becerra and Badrinarayanan, 2013). Additionally, a brand evangelist submits content unsolicited from the brand; he or she acts as an unpaid spokesperson of the brand (Doss, 2014). We define brand evangelism as a consumer who engages in online conversations about a brand consistently with the intention to persuade others to favor that brand. The key aspect of brand evangelism, and what truly makes it so impactful, is that the brand evangelist has the intention to persuade others regarding their favored brand through consistently and repeatedly advocating for a brand. Brand evangelism provides many benefits to the firm, with the crucial aspect of having the distinct power to influence consumer behavior and provide marketplace advantages for firms beyond the firm's control. This is why brand evangelism has evoked a strong interest for marketing researchers and practitioners to understand the nature and outcomes of brand evangelism.

If consumers are to turn into brand evangelists they must have a deep understanding of the brand (Yan, 2011). Brand evangelists are strongly pro-brand and actively engage in word-of-mouth promotion, persuasion, and recruitment of new consumers and disparagement of rivals (Dwyer, Greenhalgh and LeCrom, 2015). Brand evangelism brings about an increased level of credibility for the firm to other 
potential consumers further developing a stronger and more loyal consumer base. Together the evangelists build more committed and meaningful brand communities (Dwyer, Greenhalgh and LeCrom, 2015), such as the ones for brand powerhouses like Apple product enthusiasts who are considered to be the pioneers of brand evangelism (Belk and Tumbat, 2005). Apple product enthusiasts are strong advocates for the brand and persuade other non-Apple users to convert to Apple products. They have a strong, positive sentiment for the brand, are committed to the brand and continue to purchase the brand over other brands. Apple users are a prime example of the type of consumers many firms aspire to obtain.

Considerable attention has been devoted to brand evangelism, but a clear framework for brand evangelism is lacking. While there is a general consensus in brand evangelism literature that brand evangelists are vital influencers possessing the ability to persuade other consumers and ultimately affect purchase intentions, there are also many gaps in the literature including how brand evangelism is defined. For instance, some have measured brand evangelism through behavioral intentions (Rozanski, Baum and Wolfsen, 1999), and word-of-mouth (Scarpi, 2010), while others have used the experience model to evaluate the consumer journey of a brand evangelist (Riivits-Arkonsuo, Kaljund and Leppiman, 2014). Furthermore, while researchers and practitioners agree brand evangelism has a significant impact on the firm, such as purchase intention, research is limited in understanding the impact on customer retention and community building potential. We believe it is critical to the successful creation and management of brand-oriented social communities to understand how brand evangelism differentially impacts consumers' long term attitudinal loyalty, such as commitment, and behavioral loyalty such as repurchase and willingness to pay higher prices. Marketers want to develop committed relationships between consumers and brands (Turri, Smith, and Kemp, 2013) with a focus on building long-term loyalty. As such, it is our key assertion that brand evangelism must become the ultimate focus of consumer-brand relationships and loyalty.

We intend to augment brand evangelism literature by developing a fuller understanding of brand evangelism with a focus on its impactful consequences. In this study we delineate two important antecedents of brand evangelism: trust and sentiment, and focus on the consequences of brand evangelism in terms of behavioral and attitudinal loyalty. The next section presents our conceptual framework and delineates our hypothesized relationships. This is integrated with key theories underlying our proposed conceptual model leading to a detailed discussion of our methodology, analysis, findings, and managerial implications. We conclude with a framework for further studies based on our main findings.

\section{CONCEPTUAL FRAMEWORK}

The proposed model (Figure 1) integrates antecedents of brand evangelism, namely, brand trust and sentiment, with consequences of brand evangelism, attitudinal and behavioral loyalty. 
FIGURE 1

PROPOSED MODEL

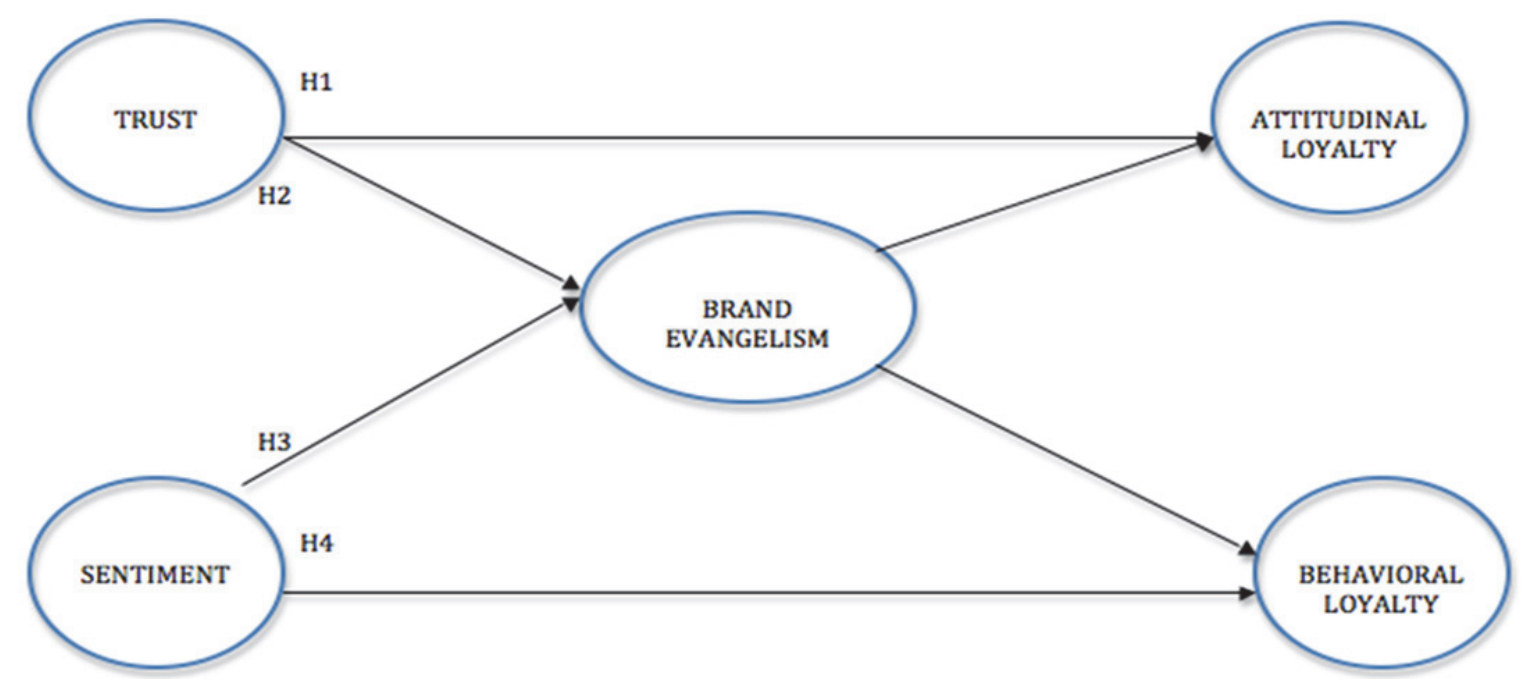

\section{Antecedents of Brand Evangelism: Trust and Sentiment}

In reviewing past literature, we discovered two variables that may be valuable precursors to brand evangelism: trust and sentiment. Consumers have both affective (sentiment) and cognitive (trust) reactions when exposed to brand stimuli (Ray, 2015). Brand trust and brand sentiment have an impact on both behavioral and attitudinal loyalty (Chaudhuri and Holbrook, 2001). We further believe the impact will be mediated by brand evangelism. If you have strong sentiment for the brand you will be a strong advocate for that brand. Likewise, if you trust a brand you will want to advocate for that brand.

\section{Brand Trust}

Brand trust is hypothesized to influence brand evangelism based on the proposition that those who have greater trust in the brand will also be stronger advocates for the brand, thus becoming devoted to the brand and having a deeper level of brand evangelism. Brand trust is the willingness of the average consumer to rely on the ability of the brand to provide its stated function (Chaudhuri and Holbrook, 2001). It is a feeling of security that the brand will meet the consumer's expectations that evolved from past experiences with the brand (Delgado-Ballester and Maunuera-Aleman, 1999). As the consumer relies on the brand and trusts the brand to always perform consistently, the consumer will exhibit behaviors in support of the brand. These behaviors may include continued willingness to purchase the brand, favorable experiences of the brand, or affection toward the brand.

Brand trust reaches beyond whether the brand meets expectations; there are also components such as brand integrity and honesty (Becerra and Badrinarayanan, 2013). Social media networks bring forth a plethora of conversations about a brand. Brands must be transparent and if they are not consumers are quick to uncover the facade. With review sites, blogs, word-of-mouth, and social networks it is not easy to hide the brand's reputation. Consumers will feel more connected to a genuine brand and engage more deeply with that brand. Consumers' trust in a brand will lead to loyalty. If a consumer distrusts a brand, has had negative experiences, or views the brand with a negative attitude they will not be committed to that brand or continue to purchase that brand. On the other hand, a consumer who trusts a brand will be more likely to continue to be committed to that brand. Brand trust can influence consumer behaviors after purchase causing long-term loyalty and strengthen the relationship between the consumer and brand (Liu, Guo and Le, 2011). Trustworthy firms deliver more value to consumers and foster greater loyalty than untrustworthy firms (Porter et al, 2012).

Morgan and Hunt (1994) found trust is required for successful relationship marketing. A brand evangelist is engaged in a committed relationship with the brand. Becerra and Badrinarayanan found 
brand trust influenced positive brand referrals (2013), which is one component of brand evangelism. Doss found trust provides a foundational support to build faith with a brand, thus leading to brand evangelism (2014). As such, we contend trust is an important antecedent of brand evangelism. Trust, its antecedents and its consequences have been widely studied in prior literature, but we are specifically concerned with the strength of the relationship between trust and loyalty when mediated by brand evangelism.

\section{H1: Trust will have a positive impact on attitudinal loyalty when mediated by brand evangelism.}

H2: Trust will have a positive impact on behavioral loyalty when mediated by brand evangelism.

\section{Brand Sentiment}

We consider brand sentiment in terms of the consumer's affection toward the brand. Brand affect is defined as the potential of a brand to elicit a positive emotional response in the average consumer as a result of its use (Chaudhuri and Holbrook, 2002). Sentiment is the overall satisfaction with the brand, or general feelings of enjoyment (Ray, 2015), over time based on the entire experience with the brand rather than just transaction-specific satisfaction (Garbarino and Johnson, 1999). Sentiment is a favorable emotional response to the brand, an emotional response that delivers a strong connection between the consumer and brand (Ray, 2015). As a result, we assert this emotional bonding with the brand will forge a deep relationship with the brand. A deep, emotional connection to a brand will allow for deep engagement and impact the potential for brand evangelism.

In a study of online brand-communities, Scarpi found consumers with affect toward the brand engaged in brand evangelism as measured by word-of-mouth (2010). However, brand evangelism cannot simply be measured by word-of-mouth as this does not account for the attachment to the brand and the brand evangelist's intention to convince others about the brand. While we posit evangelism is not measured by affect, we believe affect will have a positive impact on brand evangelism. We hypothesize consumers who feel good when they use or think about the brand will be more likely to want to have a relationship with that brand and broadcast their good experiences on behalf of the brand. If a consumer does not possess a strong sense of brand sentiment they will be less likely to be an evangelist for that brand. In the past, satisfaction was treated as a key construct in predicting consumer behavior (DelgadoBallester and Maunuera-Aleman, 1999). But in recent years, it has been found that consumers with strong positive sentiment for a brand tend to have a greater commitment for that brand (Chaudhuri and Holbrook, 2002) resulting in long-term attitudinal loyalty for the brand (Iglesias, Singh and BatistaFoguet, 2011). Extending this line of reasoning, this study predicts that brand evangelism will act as a key mediator in the relationship between sentiment and attitudinal loyalty.

\section{H3: Sentiment will have a positive impact on attitudinal loyalty when mediated by brand evangelism.}

\section{H4: Sentiment will have a positive impact on behavioral loyalty when mediated by brand evangelism.}

\section{Brand Evangelism}

Consumers that influence other consumers, also known as opinion leaders, have been studied for decades. In 1987, Feick and Price expanded on opinion leadership literature when they established the theory of the Market Maven. Market Mavens are individuals who have information about many kinds of products, places to shop and other facets of the market. They initiate discussion and respond to information requests from other consumers (Feick and Price, 1987). Market Mavens are motivated to learn about products and brands and spread the knowledge to other consumers (Laughlin and MacDonald, 2010). Social media, specifically social networking sites like Facebook and Twitter, have made it very easy for market mavens and opinion leaders to engage in online conversations with brands or with consumers discussing brands. Consumers can recommend a brand or share their personal experiences, their opinions or information about a product or brand from their own social networking sites without 
having to go to a review page and post an online review. These consumers become influencers in the marketplace, influencing other consumers to make shopping decisions.

A brand evangelist is more intense and passionate than the Market Maven (Matzler, Pichler and Hemetsberger, 2007). A brand evangelist is someone who consistently shares positive information regarding their favorite brand(s) with others in their social communities and beyond. They do not have general marketplace information, but rather, brand-specific information demonstrating their strong sense of passion and commitment. The consistent nature of their brand advocacy increases the persuasion of the consumers receiving the information.

The persuasive power of brand evangelism has been an interest to researchers and practitioners for over 10 years, yet brand evangelism is a blurred concept that has had some disagreement in the general definition. The literature surmises that brand evangelism is a powerful tool that is critical to the firm as the content can have a great impact, positively or negatively, over how other consumers view the brand and ultimately affect purchase intentions. While literature agrees on the importance of brand evangelism, research varies on how brand evangelism is defined. Pimentel and Reynolds assert brand evangelists feel a need to convince or recruit others to purchase the brand (2004). Matzler, Pichler and Hemetsberger describe brand evangelism as an active and committed way of spreading positive opinions and trying to persuade others to become engaged in the same brand (2007). Becerra and Badrinarayanan define brand evangelism as the active behavioral and vocal support of a brand, including actions such as purchasing the brand and disseminating positive brand referrals (2013). Riivits-Arkonsuo, Kaljund and Leppiman define brand evangelism as a strong consumer-brand relationship that manifests itself as an extension of positive consumer-to-consumer word-of-mouth communication (2014). A brand evangelist submits content unsolicited from the brand; he or she acts as an unpaid spokesperson of the brand (Doss, 2014). The brand has little or no control over the brand evangelist.

In this study we define a brand evangelist to be a consumer who engages in online conversations about a brand consistently with the intention to persuade others to favor that brand. A brand evangelist will openly discuss the brand, recommend the brand or give advice about the brand on social media in the form of user-generated content (UGC), such as online reviews, social networking posts, blogs, and images. If the brand evangelist is in favor of a brand or product they will continue to submit positive content regarding that brand or product, and they are often referred to as a true fan of the brand. On the other hand, the brand evangelist may submit negative content regarding alternate brands or products in trying to persuade other consumers to accept the brand for which they are advocating. Brand evangelism is a deep level of engagement while influencing other community members' perceptions and feelings toward the brand. We assert continuous, long-term brand evangelism will positively impact loyalty building as it will influence attitudinal loyalty with a commitment toward the brand and act as a deterrent for switching brands, as well as influence behavioral loyalty with repurchase intentions and willingness to pay higher prices.

There are many driving factors for brand evangelism, but extant research has not developed a clear and cohesive framework for the antecedents and consequences of brand evangelism. In 2007, Smith, Menon and Sivakumar examined the influence of recommendations on consumer decision-making during online shopping experiences. They found a large proportion of consumers adopt the peer recommended option especially when they are overwhelmed by the amount of information that is available to them during the online shopping experiences. Considering recommendations through WOM or peer reviews reduces search costs for consumers and also minimizes risk (Cole et al, 2011). Consumers trust peers who have extensive knowledge of the brand or product they are evaluating (Smith, Menon and Sivakumar, 2007). Brand evangelism is much more than mere WOM since the consumer is such a strong advocate for the brand. The brand evangelist has a deep connection to the brand and consistently advocates for the brand, they portray their extensive knowledge of the brand, and other consumers trust the brand evangelist's expertise when making their purchasing decision.

In 2013, Becerra and Badrinarayanan examined consumer-brand relationships that influence brand evangelism. They found that consumers' cognitive and emotional depictions of trust and brand identification, respectively influenced their brand-related purchase and referral intentions. Becerra and 
Badrinarayanan (2013) discuss purchase intentions, referrals and oppositional referrals as representations of brand evangelism, whereas we discuss repeat patronage intentions in terms of a loyalty outcome, as a consequence of brand evangelism. In addition, this paper identifies the importance of the emotional aspect of this buyer-seller relationship by using sentiment as a key determinant of brand evangelism and loyalty, and incorporates both aspects of loyalty, namely, attitudinal and behavioral loyalty as related but mutually exclusive outcomes.

\section{Consequences of Brand Evangelism: Attitudinal Versus Behavioral Loyalty}

As mentioned earlier, this study argues that loyalty should be necessarily studied as two distinct yet related constructs that predicate two very different types of outcome behaviors.

We examine the consequences of brand evangelism by focusing on two separate types of loyalty outcomes. Behavioral Loyalty, as the consumer's actual repatronage of the brand, as demonstrated by their behavioral intentions, measured by their likelihood of purchasing the brand in the future and their willingness to pay higher prices, versus Attitudinal Loyalty, as demonstrated by their attitudinal intentions, measured by their commitment and sense of bonding with the brand and their passionate support for the brand over other brands in the category.

Behavioral Loyalty is a construct that has been studied extensively in marketing literature. Such loyalty has evolved from being considered a pattern of repeat purchasing in the 1970s to a deeply held intention to re-buy or re-patronize a preferred product or service consistently in the future without regard for extenuating situational circumstances (Oliver, 1999). This slowly started to create a shift from loyalty being viewed as a macro-behavior of purchasing habits (behavioral loyalty) to micro-behaviors of attitude, beliefs, and emotions (attitudinal loyalty) (Dick and Basu, 1994). During the evolution of the loyalty construct from simple patterns of repeat purchasing to a deeply held sense of commitment and bonding with a brand, it started to be connected to a deeper understanding of emotional attachment with the brand (Chaudhuri and Holbrook, 2002). Loyalty is a multi-dimensional construct and in this study we delineate loyalty into two mutually exclusive but related categories: attitudinal loyalty, or the emotional attachment to the brand, and behavioral loyalty, or the repeat patronage of the brand.

Brand loyalty has long been considered a key marketing outcome in literature, especially in highly competitive markets (Delgado-Ballester and Maunuera-Aleman, 1999). However, with the advent of online shopping, and its exponential increase in popularity in recent years, it is evident that there are too many choices facing the average consumer, and these choices are constantly being influenced by peer reviews, in a context where there are no geographical boundaries, thus creating easy switching opportunities. It is increasingly difficult to retain consumers in this fiercely competitive digital landscape, thus making well calculated and savvy strategic efforts to do so, even more critical than ever before. Brands with high behavioral loyalty will experience greater market share due to high levels of repeat purchases (Chaudhuri and Holbrook, 2002), and will also create resistance for loyal consumers to fall prey to competitive strategies (Dick and Basu, 1994) thus creating entry barriers for competitors (Delgado-Ballester and Maunuera-Aleman, 1999). This is clearly evident in the case of brands such as Apple, Starbucks, Amazon to name a few. Retaining consumers is considered to be more cost effective than attracting new consumers, as revenues generated by loyal consumers continue to increase as long as the consumer remains loyal to the brand (Ray, 2015), which makes loyalty an integral business strategy. The empirical examination of brand evangelism's role in determining such loyalty outcomes is not only imperative to practitioners but to consumer behavior theorists who have long focused on the cognitive versus affective aspects of loyalty. This study proposes an amalgam of these disparate constructs to shed much needed light into the new nature of consumption related experiences and resulting loyalty relationships.

Attitudinal Loyalty

Commitment is a construct of brand loyalty that refers to the emotional attachment to the brand. Attitudinal loyalty is not created as a result of a one-time transaction; it is fostered throughout a long-term relationship with the brand and manifested in a desire to maintain the relationship with that brand 
(Evanschitzky et al, 2006). Committed consumers identify with trust and are emotionally connected to the brand (Evanschitzky et al, 2006). Such emotional attachment to the brand provides the consumer with a decision on whether they want to continue to engage with the brand (Iglesias, Singh and Batista-Foguet, 2011). Brand commitment reduces uncertainty thus saving the consumer the cost of seeking new exchanges with other brands (Chaudhuri and Holbrook, 2002).

Consumers expect that the brand will not let them down. Relying on the brand to continue to meet their expectations is a reflection of trust. Therefore, trustworthy relationships with brands lead to committed relationships with brand (Chaudhuri and Holbrook, 2002). For this reason, we hypothesize that trust will impact attitudinal loyalty and will be mediated by brand evangelism, as those consumers who trust brands strongly, will be more committed to the brand, resulting in deeper engagement, bonding and passion for the brand.

Consumers' expectations have increased as brands strive to uphold their place in social media environments (Labrecque, 2014). Individuals are engaging in online social communities both with other individuals and with brands (Zhang, Shabbir and Pitsaphol, 2014). There are escalating numbers of interactions in social media environments, and brands find themselves constantly having to preserve intimate one-on-one relationships with their consumers. Labrecque (2014) uses Para-social Interaction Theory to explain that the sense of feeling connected with a brand goes beyond the immediate interactions themselves and drives increased feelings of loyalty intentions (2014). Based on the above line of reasoning, the commitment of such deeply meaningful, passionate and continuous engagement with a brand is reflective of this important central construct of brand evangelism and its role as a key determinant of attitudinal loyalty.

\section{Behavioral Loyalty}

This study defines behavioral loyalty, also known as purchase loyalty (Turri, Smith and Kemp, 2013), as repeatedly purchasing a specific brand over a period of time regardless of situational influences and marketing efforts (Oliver, 1999). The consumer has purchased the brand in the past and will likely continue to purchase the brand in the present and in the future (Kumar and Advani, 2005). Loyal consumers with positive sentiment toward the brand and who advocate for the brand will show their loyalty to the brand through the behaviors of repeatedly purchasing the brand, purchasing the brand over other brands, and even purchasing the brand when it has a higher price over comparable brands. The customer has control over brand loyalty as they make the decisions to maintain the relationship by continuing to purchase and pay higher prices, which indicates a strong sense of loyalty to that brand (Chaudhuri and Ray, 2003). The strong bond with the brand, referrals for the brand, and trust that the brand will meet expectations will provide a strong influence on behavioral purchase intentions. Therefore, we assert brand evangelism will impact behavioral loyalty.

\section{METHOD}

\section{Data Collection}

Data was collected from 223 respondents, between the ages of 18 and 35, via Qualtrics online surveys. Incomplete surveys were discarded for a total of 161 usable surveys $(\mathrm{N}=161$.) The survey tested the variables in the model: brand evangelism, trust, brand affect, brand commitment, purchase intention, and re-purchase intention. The surveys began with an introductory statement assuring respondents of full confidentiality and anonymity. The statement was followed by various measures related to the study and demographic information questions.

\section{Measures}

Multi-item scales, based on the literature, were used to measure the participants' responses. Aside from demographic questions all measures were based on a seven-point rating scale of agreement from 1 (very strongly disagree) to 7 (very strongly agree.) The scales were adapted for the purposes of the study. Using the brand trust scale (Chaudhuri and Holbrook, 2001), trust was measured by agreement with the following two statements: "I trust the brand" and "I rely on the brand." 
Sentiment was measured using the brand affect scale and the affective brand commitment scale (Chaudhuri and Holbrook, 2001). The following five statements were measured: "I feel good when I use this brand," "This brand makes me happy," "I feel rewarded when I buy this brand," "I get excited when I think of buying this brand," and "I feel personally satisfied when I buy this brand."

Brand evangelism was measured using the positive brand referrals scale (Power et al, 2008) and the word-of-mouth intention scale (Grappi et al, 2013). The following four statements were measured: "If my friends were looking for this product, I would tell them to buy this brand," "I transmit my personal experiences with this brand also to other people I know," "I give advice about this brand to people I know," "I talk about this brand because it offers really good products."

Attitudinal loyalty was measured using the repurchase intention scale (Heitmann et al, 2007) and the brand commitment scale (Chaudhuri and Holbrook, 2001.) The following two statements were measured: "Advertisements regarding competing brands are not able to reduce my interest in the same product again" and "I am committed to this brand."

Behavioral loyalty was measured using the repurchase intention scale (Heitmann et al, 2007) and the brand commitment scale (Chaudhuri and Holbrook, 2001.) The following two statements were measured: "I am willing to pay a higher price for this brand over other brands" and "I will buy this brand over other brands."

Confirmatory factor analysis (CFA) was performed using AMOS to assess the reliability and validity of the constructs in the study. All the scales met the recommended standard for construct reliability of .60 or greater. The proposed measurement model is acceptable with c2 125.96 and 81 degrees of freedom. The normal fit index (NFI) is .86, the comparative fit index (CFI) is .94, and the root mean square (RMSEA) is .07. The results of the CFA, description of scale items, and scale reliabilities are provided in Table 1.

\section{TABLE 1 \\ SCALE ITEMS AND CONFIRMATORY FACTOR ANALYSIS RESULTS}

\begin{tabular}{lcc} 
Scale Items & Factor Loadings & $\mathbf{a}$ \\
\hline 1. Trust & & $\mathbf{0 . 7 8 5}$ \\
Trustworthiness & 0.639 & \\
Reliability & 0.925 & $\mathbf{0 . 8 9 6}$ \\
2. Sentiment & & \\
Feel Good & 0.726 & \\
Happy & 0.795 & \\
Rewarded & 0.742 & \\
Excited & 0.776 & $\mathbf{0 . 8 5 8}$ \\
Satisfied & 0.839 & \\
3. Brand Evangelism & & \\
Recommend & 0.803 & \\
Talk About & 0.836 & $\mathbf{0 . 6 1 3}$ \\
Give Advice & 0.906 & \\
Transmit Experiences & 0.843 & \\
4. Attitudinal Loyalty & & $\mathbf{0 . 6 5 6}$ \\
Committed & 0.541 & \\
Ads Don't Reduce Interest & 0.895 & \\
5. Behavioral Loyalty & & \\
Higher Price & 0.828 & \\
Purchase Over Other & & \\
Brands & 0.829 & \\
\hline
\end{tabular}




\section{RESULTS}

SEM using AMOS was used to test the hypothesized relationships. While there was a significant relationship between trust and attitudinal loyalty ( $(.251)$ as well as trust and behavioral loyalty ( $(3.321)$, there was no significant relationship between trust and brand evangelism or brand evangelism and behavioral loyalty. These surprising findings are discussed in greater detail in the next section. Furthermore, support was found for the remaining hypothesized paths with a significant relationship between brand evangelism and attitudinal loyalty ( $($.252), sentiment and brand evangelism ( $($.603), sentiment and attitudinal loyalty ( $(.374)$, and sentiment and behavioral loyalty ( $(.408)$. Thus, providing strong positive support for the role of sentiment as a key predictor of loyalty outcomes when mediated by brand evangelism. Implications of all the above findings are discussed later.

Table 2 provides the coefficients of the test of the model using path analysis in SPSS. Of the eight hypothesized relationships, six were significant with beta coefficients ranging from .25 to .60 .

\section{TABLE 2}

\section{PATH ANALYSIS}

Path

Coefficient

$\beta$

Other Paths

Trust ---> Attitudinal Loyalty

0.251

Trust ---> Behavioral Loyalty

0.321

Brand Evangelism ---> Attitudinal Loyalty

0.252

Sentiment --->Brand Evangelism

0.603

Sentiment ---> Attitudinal Loyalty

0.374

Sentiment --->Behavioral Loyalty

0.408 
FIGURE 2

\section{PATH ANALYSIS}

PATH ANALYSIS

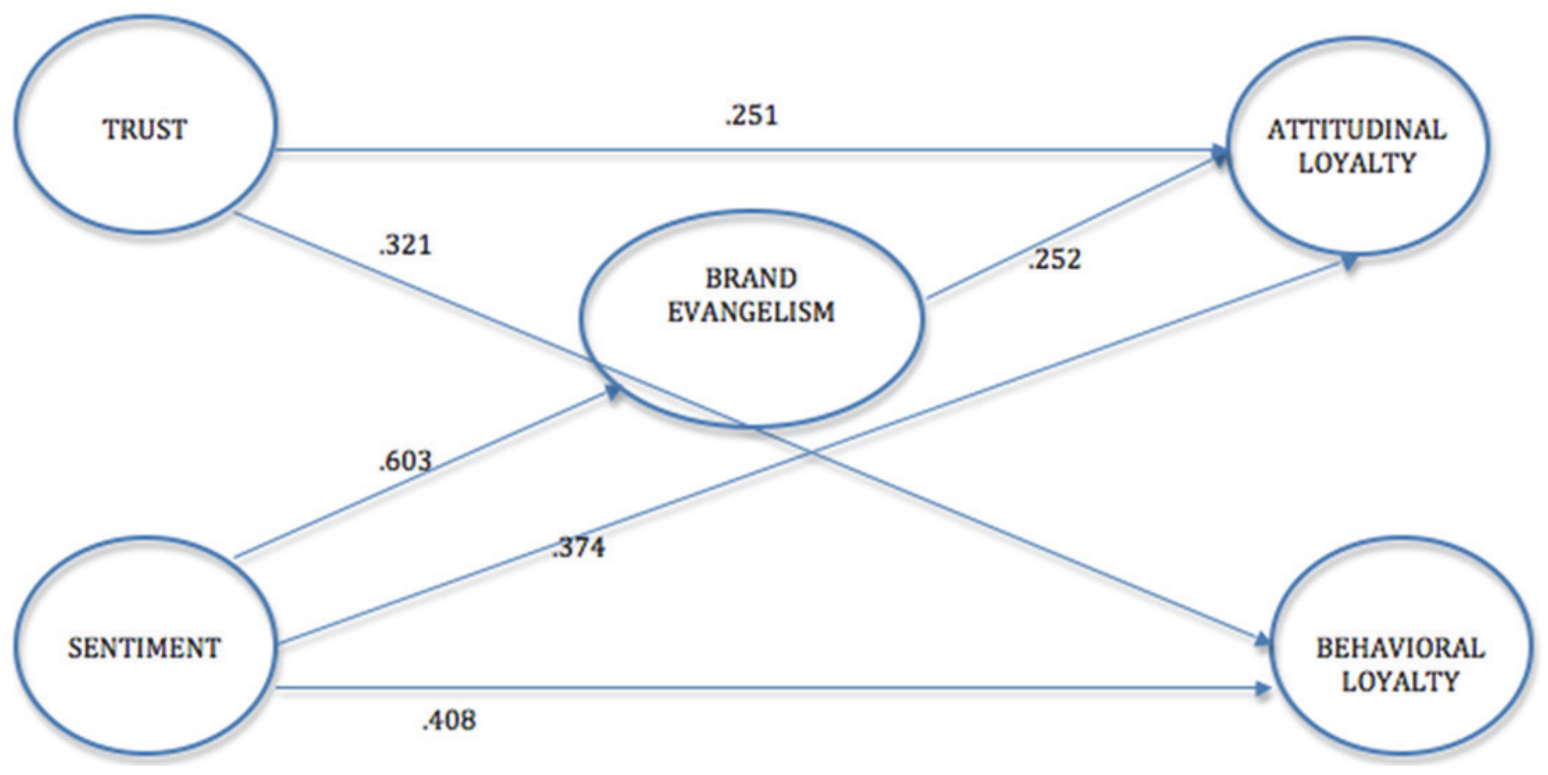

Figure 2 shows the final structural model as a result of the SEM analysis using AMOS. As evident from the results, trust did not have a significant impact on brand evangelism (.055) and brand evangelism did not have a significant impact on behavioral loyalty (.075). Thus negating the prediction that trust would impact loyalty outcomes via brand evangelism. After statistically controlling for these two trustbrand evangelism - mediated paths the model fit did not improve significantly. As such, to keep the integrity of the full model based on the theory and conceptualization, the original hypothesized paths were retained for the final model fit. The $\mathrm{c} 2$ for the final model was is 126.3 , NFI was .84, CFI was .93, and RMSEA was .08. The SEM results confirmed the path analysis findings presented before and the coefficients and fit indices are presented as evidence for this support in Table 3. 
TABLE 3

SEM PATH COEFFICIENTS AND MODEL FIT INDICES

\begin{tabular}{|c|c|}
\hline \multicolumn{2}{|c|}{$\begin{array}{l}\text { SEM Path coefficients } \\
\text { and model fit indices } \\
\text { using AMOS }\end{array}$} \\
\hline Trust -> Aloy & .639 \\
\hline Trust -> Bloy & .570 \\
\hline Sent -> Aloy & .206 \\
\hline Sent -> Bloy & .343 \\
\hline Sent $->$ BE & .753 \\
\hline BE ->Aloy & .522 \\
\hline$c^{2}$ & 126.3 \\
\hline DF & 83 \\
\hline NFI & .84 \\
\hline CFI & .93 \\
\hline RMSEA & .08 \\
\hline
\end{tabular}

\section{FINDINGS}

The study made several revealing and significant contributions to the literature. First, contrary to the literature, we did not find trust to be a strong predictor of brand evangelism. This was surprising since past research has identified trust as influencing loyalty outcomes of brand evangelism such as purchase intentions (Becerra and Badrinarayanan, 2013). In this study we identify purchase intentions as a consequence of brand evangelism in loyalty. The findings are similar that trust influences purchase intention, however we measure brand evangelism through the consumer's behavior of acting to persuade other consumers through transmitting personal experiences, recommending the brand, talking about the brand and giving advice about the brand. This non-finding is significant especially in the context of social communities as it shows trusting the brand is not enough to become a deeply committed advocate in the brand. Trust takes time to build and in this digital age of extensive choices, constant change and speedy interactions a consumer may not have developed a strong trusting bond with the brand however they may have sentiment for the brand. Sentiment is based on feelings and emotions, which are more transient in nature and change often. An emotional attachment to the brand (sentiment) will create that deep commitment and desire to be a strong evangelist for the brand.

Consistent with prior literature trust influenced both attitudinal and behavioral loyalty, but what was rather surprising was that the impact was a direct one and not mediated by brand evangelism as predicted in this paper. As many authors in the past including Liu et al (2011) suggested, trust in the brand impacts behavioral intentions positively. Consumers who found the brand to be reliable and trustworthy would express strong intentions to continue to use the brand, which is supported in this study as well. However, although Doss (2014) and Becerra and Badrinarayanan (2013) found that trust was a key antecedent of various dimensions of brand evangelism, such as building faith with a brand and positive brand referrals respectively, our study did not find such support. This finding definitely sheds some meaningful light on the brand evangelism literature making it imperative to investigate on a larger scale across multiple social media platforms and product categories.

Another key finding and contribution of this study, as predicted, was that brand sentiment had a significant impact on brand evangelism as well as both behavioral and attitudinal loyalties. While marketing literature has established sentiment as a factor influencing loyalty, this study makes a significant contribution to extant literature by demonstrating brand evangelism's role as a key mediator on loyalty outcomes, which has not yet been examined in literature. 
Another interesting finding is that although prior literature defines a brand evangelist as a vocal advocate of the brand, who actively supports the brand by repurchase behavior (Becerra and Badrinarayanan, 2013) we did not find that to be the case in this study. The direct impact of brand evangelism on behavioral loyalty was not significant. At first glance, this may seem rather counterintuitive but on further examination, it may very well be that a brand evangelist shares a deep sense of commitment and bonding with the brand, nurtures a longstanding favorable opinion of the brand while making active efforts to recruit others to choose the brand, it does not necessarily mean that they frequently purchase the brand. For instance, consumers may consider themselves to be a Tesla brand evangelist, and they may strongly advocate on behalf of the brand frequently, but that does not necessarily mean that they buy a Tesla car when they need to make a purchase. They may even spend hours discussing the brand online without having made a purchase themselves, simply because they cannot afford it. There is also an aspirational aspect to being a brand evangelist. Simply by being associated with prestige brands such as Tesla, Starbucks, or Apple, one can match one's self-concept with that of the brand's thereby enhancing one's own sense of self-worth.

\section{MANAGERIAL IMPLICATIONS}

The study provides some key strategic insights with real implications for marketing managers. We suggested brand evangelists act on their own behalf and managers have little to no control over them. Our study found important variables, such as trust and sentiment, which managers can control to impact a brand evangelism and/or loyalty strategy. Practitioners and researchers agree with the role and critical importance of brand evangelism in creating and growing loyalty over time. Marketing managers search for brand evangelists, look for ways to recruit them, or seed them with products in hopes of positive brand referrals and gaining a long-term relationship with someone who will continue to persuade others to favor their brand. Are managers looking in the right places? Managers must be careful not to solicit just any active participant of social media; rather their focus and search must be guided by the right kind of spokesperson. A person who will be influential as the brand ambassador in the world of social and mobile media and bring many others into the brand community. Mere levels of interaction and even engagement do not equate with a brand evangelist's commitment and sense of bonding with the brand. Someone with a deep attachment to the brand, looking for a lasting long-term relationship with the brand and the desire to persuade others about the brand may be more difficult to find among the masses of users who continuously engage in UGC. Some managers may think they can turn anyone into a brand evangelist, but as our study points out, this is not the case. Simply speaking, engagement is not a sufficient and accurate predictor of brand evangelism.

While Morgan and Hunt (1994) found trust to be a driving force for a successful consumer-brand relationship and Becerra and Badrinarayanan (2013) found brand trust influenced positive brand referrals, we do not find support for brand trust influencing brand evangelism. Managers who begin strategies to strengthen brand trust to increase brand evangelism may be missing the mark. It is important for a manager to determine what objective they are trying to satisfy. Trust significantly influences attitudinal and behavioral loyalty and would be an appropriate strategy to strengthen consumer loyalty. Brand evangelism does not mediate this relationship. So, even though trust is a necessary and much studied indicator or loyalty and without trust it is near impossible to sustain loyalty, it is not enough. For someone to become a brand evangelist, sentiment more than trust comprises the key ingredient. It is how a brand makes us feel more than think that matters. How a brand continues to make us feel positive sentiments helps us feel more attached to the brand and share a sense of belonging. This bond and attachment is what makes an active social media presence a true evangelist. It translates to taking risks for the brand, standing up for the brand against criticism, waiting in line for days to acquire the brands new offerings and willingness to pay more, buy more, act more on behalf of the brand.

This study found sentiment to be the strongest predictor of brand evangelism and both attitudinal and behavioral loyalty. This is an important revelation for managers. Sentiment is different than the brand's reliability and trustworthiness, or the practical usage of the brand; sentiment is the consumer's emotional 
connection to the brand, or how the consumer feels about using the brand. The emotional connection elicited through sentiment provides a strong commitment to the brand resulting in brand evangelism and loyalty. Increasing brand sentiment is a strategy that will produce strong outcomes, such as a brand evangelist who will persuade others about the brand or loyalty in the form of repurchase intentions and choosing the brand over other brands. When consumers have high sentiment for the brand they feel good, happy, rewarded, and satisfied when they use the brand. They also feel excited when they think of the brand. Managers should consider incorporating these key factors into their marketing strategy. There are brands that have put this into practice, such as Toms ${ }^{\circledR}$, who brands itself as the "One for one company" where they pledge to help a person in need with every product purchase. A consumer can feel rewarded and good about the purchase they made when they know they are helping someone else. This is one strategy to increase brand sentiment and ultimately influence loyalty.

Finally, our study shows brand evangelism does not directly and significantly influence behavioral loyalty, which is essential to consider when marketing managers are creating their marketing strategies. We ask the question again - what outcome is the marketing manager looking for when they are seeking out brand evangelists? Do they want to increase the amount of people who are deeply connected to their brand who will continue to persuade others about the brand? Are they looking for the brand's passionate ambassadors with a deep intention to recruit new customers and switch others from competitive brands? If so, then brand evangelists are the perfect kind of customers whose lifetime value and worth to the brand far surpasses their frequency of repeat purchases.

\section{LIMITATIONS AND DIRECTIONS FOR FUTURE RESEARCH}

There are limitations with the study that provide avenues for additional research. While the survey instrument was equitably distributed through social media to men and women, the respondents were predominantly female. It would be interesting to see how gender might influence the model when a larger and more randomly selected sample with equal numbers of men and women are selected. It is possible that sharing their experiences in detail and with intensely positive passion makes women feel like they are leaders in their social communities and may even enhance their self-esteem. The need for self-esteem enhancement and its ultimate achievement may be an important motivation orientation which needs to be studies further to explain why some people feel the need to be outspoken and loud brand evangelists. There is some evidence in literature that when female consumers feel accepted by others in social communities to tout products and brands, they will continue to do so as long as that need for acceptance is being met. (Fan and Miao, 2012). Men and women use the Internet almost equally but they have different attitudes and behaviors related to shopping (Porter, Donthu and Baker, 2012). Women may be more likely to be social media mavens than men (Lester et al, 2012.) For these reasons, gender's role as a moderator may be essential to examine especially when it relates to sentiment, engagement, commitment and loyalty.

Another potential limitation is that this study did not focus on one specific brand. Participants were asked to think about a favorite brand that they frequently purchased. This was done to capture the nature of holistic brand evangelism as a determinant rather than a product or brand specific concept. Perhaps by studying and comparing specific groups of brand evangelists, and asking about their relationship with the particular brand or product category in question, the strength and variance of the relationships could be assessed more accurately. It is also possible that brand evangelists have a deep connection to the brand far beyond the practical uses of the brand's offerings. If the brand exhibits authentic altruism, the consumer may identify with this brand more deeply and meaningfully and be more committed to supporting the brand. Brand altruism may strengthen the relationship between brand evangelism and loyalty and potentially influence deeper behavioral loyalty. We have not found altruism to be a variable of consideration in past research, but this may be worth investigating in the future.

Additionally, brand evangelism literature is limited in the understanding of behavioral traits that may drive evangelism. Other research has focused on behavioral traits that increase user engagement, but have not identified these traits in a brand evangelist. If we can identify evangelism traits within the individual 
then practitioners may seek out specific consumers who they can turn into brand evangelists (Laughlin and MacDonald, 2010.) Park, Ahn and Kim found the desire for entertainment, information and efficiency are the primary drivers for blogging behavior (2010.) Research has not ascertained the behavioral characteristics of a brand evangelist.

Lastly, we would be interested to see how personality characteristics would influence our model. For instance would extraversion or openness impact the relationships between trust and sentiment with brand evangelism? Vazifehdoost, Akbari and Charsted applied the "Big 5" personality traits (extraversion, agreeableness, conscientiousness, neuroticism, openness) to market mavens and found market mavens only scored high on extraversion and openness (2012.)

Pagani, Goldsmith and Hofacker found that extraversion combined with social identity expressiveness acts as a motivation for social media usage (2013.) Clark and Goldsmith studied psychological traits of market mavens finding that market mavens tend to conform to social norms and they are somewhat susceptible to the normative influences of those who are more likely to conform (2005.) Further empirical research should consider applying these constructs to study brand evangelists at a more granular level.

\section{REFERENCES}

Becerra, E., \& Badrinarayanan, V. (2013). The influence of brand trust and brand identification on brand evangelism. Journal of Product and Brand Management, 22(5/6), 371-383.

Belk, R.W., \& Tumbat, G. (2005). The cult of Macintosh. Consumption Markets \& Culture, 8(3), 205217.

Chaudhuri, A., \& Holbrook, M.B. (2001). The chain of effects from brand trust and brand affect to brand performance: The role of brand loyalty. Journal of Marketing, 65(April), 81-93.

Chaudhuri, A., \& Holbrook, M.B. (2002). Product-class effects on brand commitment and brand outcomes: The role of brand trust and brand affect. Brand Management, 10(1), 33-58.

Chaudhuri, A., \& Ray, I. (2003). Relationships between satisfaction, trust, and commitment in a retail environment. American Marketing Association, 14(Winter), 138-144.

Chen, H., \& Huang, C. (2012). An investigation into online reviewers' behavior. European Journal of Marketing, 47(10), 1758-1773.

Clark, R.A., \& Goldsmith, R.E. (2005). Market mavens: Psychological influences. Psychology and Marketing, 22(4), 289-312.

Cole, M.D., Long, M.M., Chiagrouris, L.G., \& Gopalakrishna, P. (2011). Transitioning from traditional to digital content: An examination of opinion leadership and word-of-mouth communication across various media platforms. Journal of Internet Commerce, 10(2), 91-105.

Delgado-Ballester, E., \& Maunuera-Aleman, J.L. (1999). Brand trust in the context of consumer loyalty. European Journal of Marketing, 35(11/12), 1238-1258.

Dessart, L., Veloutsou, C., \& Morgan-Thomas, A. (2015). Consumer engagement in online brand communities: a social media perspective. Journal of Product and Brand Management, 24(1), 2842.

Dick, A.S., \& Basu, K. (1994). Customer loyalty: Toward an integrated conceptual framework. Journal of the Academy of Marketing Science, 22(2), 99-113.

Doss, S.K. (2014). Spreading the good word: Toward an understanding of brand evangelism. Journal of Management and Marketing Research, 1-16

Dwyer, B., Greenhalgh, G.P., \& LeCrom, C.W. (2015). Exploring fan behavior: Developing a scale to measure sport eFANgelism. Journal of Sport Management, 29, 642-656.

Evanschitzky, H., Iyer, G.R., Plassmann, H., Niessing, J., \& Meffert H. (n.d.). The relative strength of affective commitment in securing loyalty in service relationships. Journal of Business Research, $59,1207-1213$. 
Fan, Y., \& Miao, Y. (2012). Effect of electronic word-of-mouth on consumer purchase intention: The perspective of gender differences. International Journal of Electronic Business Management, 10(3), 175-181.

Garbarino, E., \& Johnson, M.S. (1999). The different roles of satisfaction, trust, and commitment in customer relationships. Journal of Marketing, 63, 70-87.

Gensler, S., Volckner, F., Liu-Thompkins, Y., \& Wiertz, C. (2013). Managing brands in the social media environment. Journal of Interactive Marketing, 27, 242-256.

Grappi, S., Romani, S., \& Bagozzi, R.P. (2013). The effects of company offshoring strategies on consumer responses. Academy of Marketing Science, 41(6), 683-704.

Heitmann, M., Lehmann, D.R., \& Herrmann, A. (2007). Choice goal attainment and decision and consumption satisfaction. Journal of Marketing Research, 44(2), 234-250.

Iglesias, O., Singh, J.J., \& Batista-Foguet, J.M. (2011). The role of brand experience and affective commitment in determining brand loyalty. Journal of Brand Management, 18, 70-582.

Kim, S., Martinez, B., McClure, C., \& Kim, S. (2016). E-WOM intentions towards social media messages. Atlantic Marketing Journal, 5(1), 137-154.

Kumar, S., Ramesh, A., \& Jai, Y.(2005). Factors affecting Brand Loyalty: A study in an emerging market on fast moving consumer goods. Journal of Customer Behaviour, 4, 251-275.

Labrecque, L.I. (2014). Fostering consumer-brand relationships in social media environments: The role of parasocial interaction. Journal of Interactive Marketing, 28, 134-148.

Laroche, M., Habibi, M.R., \& Richard, M. (2013). To be or not to be in social media. How brand loyalty is affected by social media? International Journal of Information Management, 33(1), 76-82.

Laughlin, J.D., \& MacDonald, J.B. (2010). Identifying market mavens online by their social behaviors in community-generated media. Academy of Marketing Studies Journal, 14(1), 59-70.

Lester, D.R., Tudor, R., Keith, L., Dolly D., \& Mitchell, T. (2012). Marketing Mavens' Fusion with Social Media. Atlantic Marketing Journal, 1(1), 79-94.

Liu, C., Guo, Y., \& Lee, C. (2011). The effects of relationship quality and switching barriers on customer loyalty. International Journal of Information Management, 31, 71-79.

Matzler, K., Pichler, E.A., \& Hemetsberger, A. (2007). Who is spreading the word? The positive influence of extraversion on consumer passion and brand evangelism. Marketing Theory and Applications, 18, 25-32.

Morgan, R.M., \& Hunt, S.D. (1994). The commitment-trust theory of relationship marketing. Journal of Marketing, 58, 20-38.

Oliver, R.L. (1999). Whence consumer loyalty. Journal of Marketing, 63, 33-44.

Padmanabhan, K.H. (2008). A hierarchy of promotional blogs. Journal of Website Promotion, 3(3/4), 153-160.

Pagani, M., Goldsmith, R.E., \& Hofacker, C.F. (2013). Extraversion as a stimulus for user-generated content. Journal of Research in Interactive Marketing, 7(4), 242-256.

Park, B., Ahn, S., \& Kim, H. (2010). Blogging: mediating impacts of flow on motivational behavior. Journal of Research in Interactive Marketing, 4(1), 6-29.

Pimentel, R.W., \& Reynolds, K.E. (2004). A model for consumer devotion: Affective commitment with proactive sustaining behaviors. Academy of Marketing Science Review, 2004(5), 1-48.

Porter, C.E., Donthu, N., \& Baker, A. (2012). Gender differences in trust formation in virtual communities. Journal of Marketing Theory and Practice, 20(1), 39-58.

Power, J., Whelan, S., \& Davies, G. (2008). The attractiveness and connectedness of ruthless brands: The role of trust. European Journal of Marketing, 42(5), 586-602.

Rapp, A., Beitelspacher, L.S., Grewal, D., \& Hughes, D.E. (2013). Understanding social media effects across seller, retailer, and consumer interactions. Academy of Marketing Science, 41, 547-566.

Ray, I. (2015). Emotional versus Functional Attributes of Delight-and Satisfaction-Mediated Effects on Customer Loyalty.

Riivits-Arkonsuo, I., Kaljund, K., \& Leppiman, A. (2014). Consumer journey from first experience to brand evangelism. Research in Economics and Business: Central and Eastern Europe, 6(1), 5-28. 
Rozanski, H.D., Baum, A.G., \& Wolfsen, B.T. (1999). Brand zealots: realizing the full value of emotional brand loyalty. Strategy and Business, 17, 51-62.

Scarpi, D. (2010). Does size matter? An examination of small and large web-based brand communities. Journal of Interactive Marketing, 24(1), 14-21.

Shadkam, M., \& O'Hara, J. (2013). Social commerce dimensions: The potential leverage for marketers. Journal of Internet Banking and Commerce, 18(1), 1-14.

Smith, D., Menon, S., \& Sivakumar, K. (2005). Online peer and editorial recommendations, trust, and choice in virtual marketing. Journal of Interactive Marketing, 19(3), 15-37.

Thomas, J.B., Peters, C.O., Howell, E.G., \& Robbins, K. (2012). Social media and negative word of mouth: Strategies for handing unexpecting comments. Atlantic Marketing Journal, 1(2), 87-108.

Turri, A.M., Smith, K.H., \& Kemp, E. (2013). Developing affective brand commitment through social media. Journal of Electronic Commerce Research, 14(3), 201-214.

Vazifehdoost, H., Akbari, M., \& Charsted, P. (2012). The role of psychological traits in market mavenism using big five model. International Journal of Management in Business Research, 2(3), 243-252.

Weinberg, B.D., de Ruyter, K., Dellarocas, C., Buck, M., \& Keeling, D.I. (2013). Destination social business: Exploring an organization's journey with social media, collaborative community and expressive individuality. Journal of Interactive Marketing, 27(4), 299-310.

Yan, J. (2011). Social media in branding: Fulfilling a need. Journal of Brand Management, 18(9), 688696.

Zhang, J., Shabbir, R., Pitsaphol, C., \& Hassan, W. (2014). Creating brand equity by leveraging value creation and consumer commitment in online brand communities: A conceptual framework. International Journal of Business and Management, 10(1), 80-91.

Zheng, X., Cheung, C., Lee, M.K., Matthew, K.O., \& Liang, L. (2015). Building brand loyalty through user engagement in online brand communities in social networking sites. Information Technology and People, 28(1), 90-106. 